Rapid communication

\title{
Atmospheric dust variability from Arabia and China over the last 500,000 years
}

\author{
Andrew P. Roberts*, Eelco J. Rohling, Katharine M. Grant, Juan C. Larrasoaña ${ }^{1}$, Qingsong Liu ${ }^{2}$ \\ School of Ocean and Earth Science, University of Southampton, National Oceanography Centre, European Way, Southampton SO14 3ZH, UK
}

\section{A R T I C L E I N F O}

\section{Article history:}

Received 27 April 2011

Received in revised form

9 September 2011

Accepted 13 September 2011

Available online 21 October 2011

\section{Keywords:}

Aeolian dust

Climate

Radiative perturbation

Glacial

Interglacial

\begin{abstract}
A B S T R A C T
Atmospheric mineral dust aerosols affect Earth's radiative balance and are an important climate forcing and feedback mechanism. Dust is argued to have played an important role in past natural climate changes through glacial cycles, yet temporal and spatial dust variability remain poorly constrained, with scientific understanding of uncertainties associated with radiative perturbations due to mineral dust classified as "very low". To advance understanding of the dust cycle, we present a high-resolution dust record from the Red Sea, sourced principally from Arabia, with a precise chronology relative to global sea level/ice volume variability. Our record correlates well with a high-resolution Asian dust record from the Chinese Loess Plateau. Importing our age model from the Red Sea to the Chinese Loess Plateau provides a first detailed millennial-scale age model for the Chinese loess, which has been notoriously difficult to date at this resolution and provides a basis for inter-regional correlation of Chinese dust records. We observe a high baseline of dust emissions from Arabia and China, even through interglacials, with strong superimposed millennial-scale variability. Conversely, the distal EPICA Dome C Antarctic ice core record, which is widely used to calculate the radiative impact of dust variations, appears biased to sharply delineated glacial/interglacial contrasts. Calculations based on this Antarctic dust record will therefore overestimate the radiative contrast of atmospheric dust loadings on glacial/interglacial timescales. Additional differences between Arabian/Asian and circum-Saharan records reveal that climate models could be improved by avoiding 'global mean' dust considerations and instead including large-scale regions with different dust source variability.
\end{abstract}

(c) 2011 Elsevier Ltd. All rights reserved.

\section{Introduction}

Wind-borne mineral dust can influence climate both directly and indirectly (Tegen et al., 1996; Kaufman et al., 2002; Maher et al., 2010). Dust can influence climate directly because it changes the radiative properties of the atmosphere by scattering and absorbing solar and terrestrial radiation (IPCC, 2007). Dust also acts as ice nuclei in clouds (Sassen et al., 2003) and modifies cloud properties, which influences the formation and lifetime of clouds and affects Earth's radiative balance (Spracklen et al., 2008) and the hydrological cycle (e.g., Arimoto, 2001). Dust deposition onto the ocean surface may affect climate indirectly by supplying iron as a micronutrient to Fe-limited waters, thereby fertilizing phytoplankton productivity (Martin et al., 1991; Jickells et al., 2005; Wolff et al.,

\footnotetext{
* Corresponding author. Present address: Research School of Earth Sciences, The Australian National University, Canberra ACT 0200, Australia

E-mail address: andrew.roberts@anu.edu.au (A.P. Roberts)

1 Present address: Instituto Geológico y Minero de España, Unidad de Zaragoza, Manuel Lasala 44 9B, Zaragoza 50006, Spain.

2 Present address: Paleomagnetism and Geochronology Laboratory (SKL-LE), Institute of Geology and Geophysics, Chinese Academy of Sciences, Beijing 100029, People's Republic of China.
}

2006; Boyd and Ellwood, 2010). Increased productivity results in drawdown of atmospheric $\mathrm{CO}_{2}$; subsequent export of biogenic carbon from surface to deep ocean waters can lead to long-term geological sequestration of carbon (e.g., Martinez-Garcia et al., 2009). It is therefore well established that aeolian dust responds to, and has a direct role in, climate change (Jickells et al., 2005; Maher et al., 2010).

It remains a crucial goal of climate research to understand the dust cycle, how it is involved in climate forcing, and how the dust cycle responds to changing climate. Anthropogenic changes to land use have been demonstrated to have major impacts on dust generation (e.g., Mulitza et al., 2010). Dust cycle models for the coming centuries predict large changes in aeolian transport from land to sea in response to anthropogenic change (e.g., Mahowald et al., 2006). Such modelling depends on understanding feedbacks between dust aerosols and radiative forcing for the past and present and the effects of dust flux changes on ocean fertilization and productivity-related atmospheric $\mathrm{CO}_{2}$ change. One key requirement is a global view of spatial and temporal variability in dust fluxes from the major dust-producing regions, including the Sahara, Arabia, central Asia, Patagonia, and Australia (Fig. 1). The northern hemisphere is responsible for up to $80 \%$ of the global atmospheric dust loading, 


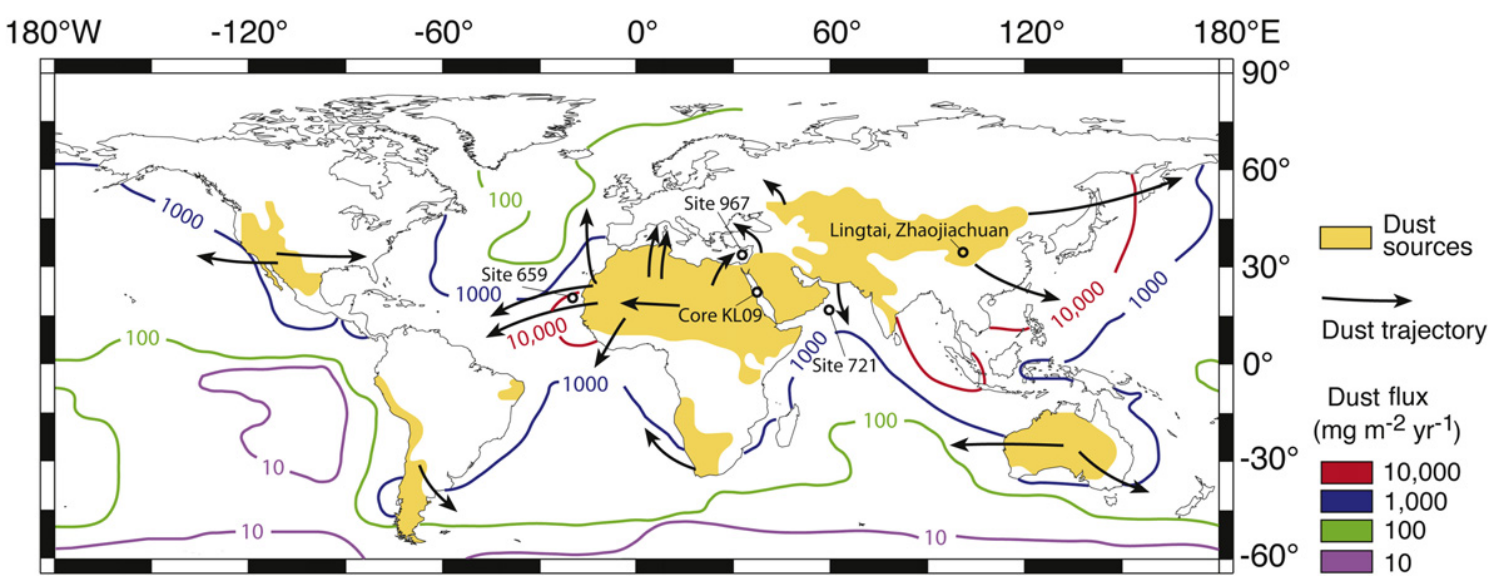

Fig. 1. Major global dust sources and locations of dust records. Dust flux contours ( $\mathrm{mg} \mathrm{m}^{-2} \mathrm{yr}^{-1}$ ) are shown in oceans surrounding dust sources (after Duce et al., 1991). Locations of dust records discussed are indicated (ODP sites 659 (Tiedemann et al., 1994), 721 (deMenocal et al., 1991), and 967 (Larrasoaña et al., 2003 ), core KL09 (this study) and the Zhaojiachuan and Lingtai loess sections (Sun et al., 2006)). Note that Antarctica lies in a distal region with low dust flux.

with the Sahara estimated to provide $40-60 \%$ of the global dust supply (Prospero et al., 2002; Maher et al., 2010). The dust belt from Arabia to the Chinese Loess Plateau represents the next major supplier of northern hemisphere dust, with Arabia producing $10-20 \%$ of global dust emissions (Maher et al., 2010). Trauth et al. (2009) compiled the longest available dust records sourced from the Sahara and Arabia. Despite the fact that these records are astronomically tuned, the records lack millennial resolution.

We present here a new dust record from marine sediment core KL09 from the central Red Sea (latitude $=19^{\circ} 57^{\prime} 36^{\prime \prime} \mathrm{N}$; longitude $=38^{\circ} 8^{\prime} 18^{\prime \prime} \mathrm{E}$; water depth $=814 \mathrm{~m}$ ), for which Arabia, and to a lesser extent eastern North Africa, are the dominant dust sources (Stein et al., 2007), and from which we have published detailed records of relative sea level (RSL) variations for the last 5 glacial cycles that span the past $520 \mathrm{kyr}$ (Rohling et al., 2009). This record has the advantage that it has a U-Th validated chronology for the major glacial/interglacial sea level changes (Rohling et al., 2010), which enables us to make a detailed comparison between our dust record and those from polar ice cores to assess spatial and temporal dust flux variability in different regions. Crucially, our dust record is co-registered with (i.e., measured on the same samples as) the RSL record from core KL09. Hence, the phase relationship of these records (Fig. 2a) is absolute. We compare our dust record with other regional dust records and discuss these comparisons in terms of their implications for understanding the global dust cycle.

\section{Methods}

We use an environmental magnetic proxy for haematite content, with which we have developed aeolian dust records for hyper-arid Saharan (Larrasoaña et al., 2003) and Arabian sources (Rohling et al., 2008). The proxy is an isothermal remanent magnetization (IRM) that was imparted to samples using an inducing field of $900 \mathrm{mT}$, followed by alternating field (AF) demagnetization at $120 \mathrm{mT}$ (IRM 900 mT@AF120 mT). The IRM was imparted using an impulse magnetizer, with $\mathrm{AF}$ demagnetization and remanence measurements made using a 2-G Enterprises superconducting rock magnetometer with in-line demagnetization capability at the National Oceanography Centre, Southampton (NOCS), UK (Roberts, 2006). Measurements were made on continuous discrete samples taken at $\sim 1 \mathrm{~cm}$ stratigraphic intervals. IRM $\mathrm{I}_{900 \mathrm{mT} @ A F 120 \mathrm{mT}}$ has been validated as an aeolian dust proxy through significant correlations between Fe and Ti abundances in the Red Sea (Rohling et al., 2008), as is also demonstrated for core KL09 in Fig. 2b. Elemental abundances were measured using an ITRAX core-scanning X-ray fluorescence system (Croudace et al., 2006), with measurements made at $0.5 \mathrm{~mm}$ stratigraphic increments at NOCS prior to sub-sampling for stable isotopic (as presented by Rohling et al. (2009)) and environmental magnetic measurements.

\section{Results and discussion}

Global dust fluxes during the last few glacial cycles are usually recognised to have been higher during glacial stages and lower during interglacials (e.g., Lambert et al., 2008; Winckler et al., 2008; Maher et al., 2010). In contrast, the highest dust fluxes in our Red Sea record coincide with glacial terminations (dashed lines in Fig. 2a) rather than with glacial stages, although dust fluxes overall were higher during glacials than during interglacials. We observe a strong similarity between our Red Sea dust record and those from the Chinese Loess Plateau (Fig. 2c and d; Sun et al., 2006). Mean quartz grain size is widely used as a proxy for wind strength on the Chinese Loess Plateau (Porter and An, 1995; Sun et al., 2006), and is plotted in Fig. 2c for two Chinese loess records and a stack of these records (Sun et al., 2006) beside our Red Sea dust record. Despite the strong similarity between the Red Sea and Chinese data sets, there appear to be chronological offsets in detail. Orbitally tuned chronologies exist for the Chinese loess (e.g., Sun et al., 2006), but the ages obtained by Sun et al. (2006) for several geomagnetic reversals in the Chinese loess remain inconsistent with those of the standard geomagnetic polarity timescale (Cande and Kent, 1995). The persistence of age offsets for geomagnetic reversals in the chronology of Sun et al. (2006) demonstrates that the longstanding problem with the chronology of the Chinese loess (cf. Liu et al., 2008 ) is not completely resolved. Construction of millennial-scale chronologies is notoriously difficult because of a lack of suitable material for precise dating. The signal similarity between the Red Sea and Chinese dust records suggests that they document the same climate variability and that it is appropriate to correlate the Chinese loess record to the Red Sea dust record. Correlation of dust records from the Red Sea and Chinese Loess Plateau (Fig. 2) provides a solution to the problem of dating the Chinese loess because the Red Sea chronology is tied through our RSL record (Rohling et al., 2009) to a sound U-Th chronology for sea level variations on glacial/interglacial timescales (Rohling et al., 2010). We use the stacked quartz grain size record of Sun et al. (2006) and tune it to our Red Sea dust record (Fig. 2d). This enables us to export 


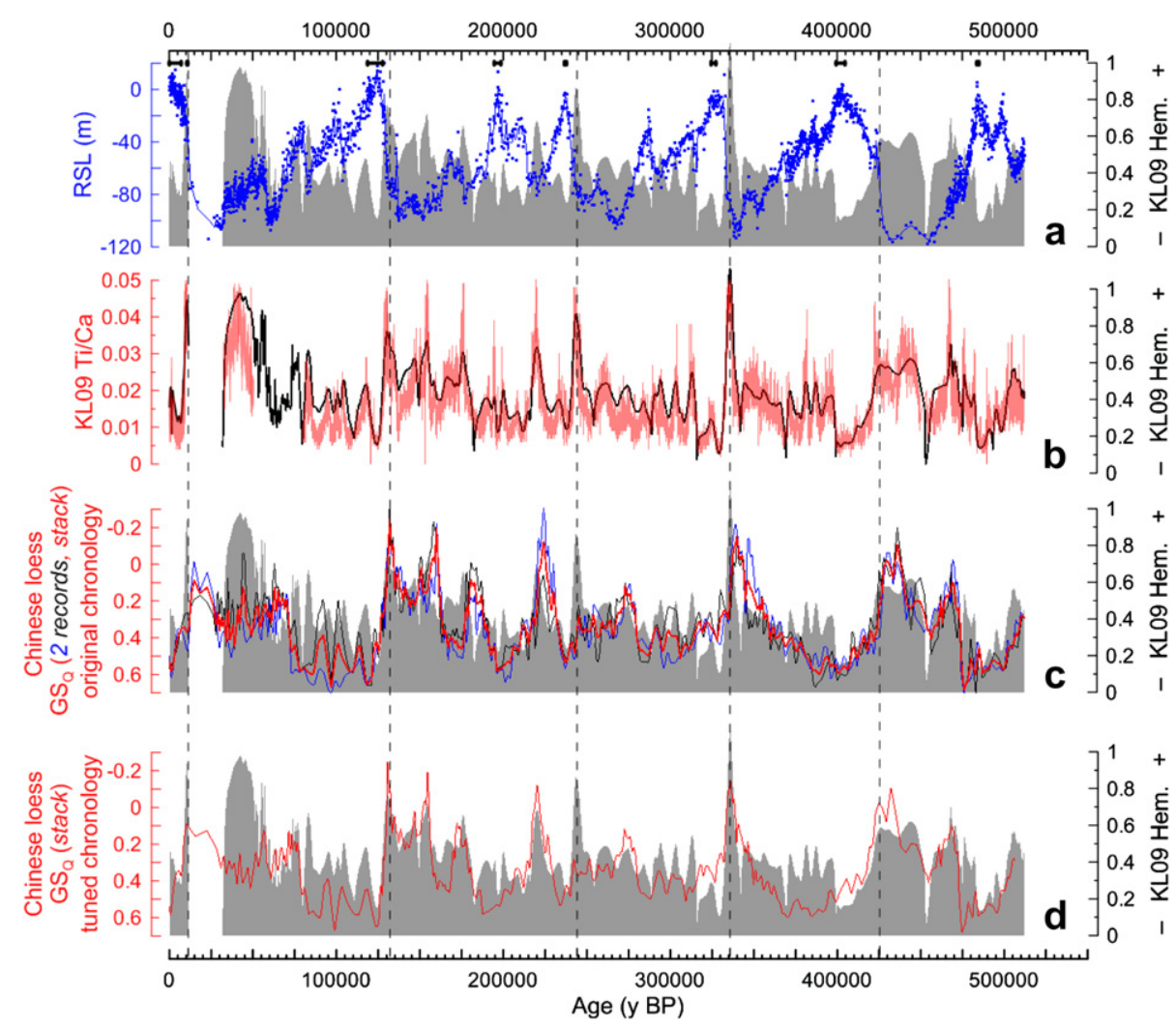

Fig. 2. Comparison of sea level and dust records for the Red Sea and Chinese Loess Plateau. (a) Sea level (blue) and dust (grey shading) for Red Sea core KL09 (sea level after Rohling et al. (2009), with chronology tied to U-Th dating of corals from Rohling et al. (2010); black tie points at top of panel). (b) Two dust proxies from Red Sea core KL09, including Ti/Ca ratio (pink) and the IRM900 mT@AF120 mT haematite (Hem.) proxy (black). (c) Comparison of our Red Sea dust record (grey shading) with two representative dust records (quartz grain size $\left(\mathrm{GS}_{\mathrm{Q}}\right)$ ) from Zhaojiachuan (blue) and Lingtai (black), Chinese Loess Plateau, on their own age model (from Sun et al., 2006), with a stack of the two records (red). (d) Comparison of our Red Sea dust record (grey shading) with the stacked Chinese loess record (red) after tuning to the Red Sea chronology of Rohling et al. (2010). $R^{2}$ values improve from 0.15 to 0.28 (for $n=1582$ data points) after tuning (both correlations are statistically significant at $P=0.01$ ). Vertical dashed lines denote dust spikes at glacial terminations. (For interpretation of the references to colour in this figure legend, the reader is referred to the web version of this article.)

a millennial chronology to the Chinese loess for the first time, for synchronizing Chinese loess records to global climate signals. Relative to sea-level/ice-volume changes, our dust chronology is precise on millennial timescales because both signals are obtained from the same samples. In an absolute (U-Th equivalent) sense, the chronology of the Red Sea sequences is well defined on glacial/ interglacial timescales (Rohling et al., 2010). However, although the absolute chronology through parts of the sequence could still be subjected to fine-tuning on millennial timescales (e.g., Rohling et al., 2008), age control through the studied record should be considered accurate to within $\pm 5 \mathrm{kyr}$.

The major dust maxima that stand out in the Red Sea and Chinese loess records at the early stages of glacial terminations II, III, IV and V (Fig. 2d) are not systematically present in Antarctic (Fig. 3b) (Lambert et al., 2008), Saharan (Fig. 3c and d) (Tiedemann et al., 1994; Larrasoaña et al., 2003) or low-resolution Arabian (Fig. 3c) (deMenocal et al., 1991) records. A dust spike also occurs at termination I in our Red Sea record, but it is less visible in Fig. 3 because the immediately underlying interval is obscured by an indurated aplanktonic zone (Rohling et al., 2008). The apparent absence of systematic dust peaks in the deglaciations in nearSaharan marine records may result from inadequate resolutions and/or chronological uncertainties. Improved records are needed to investigate this in detail.

Winckler et al. (2008) concluded that there is a high degree of correlation between dust fluxes in the equatorial Pacific and Antarctica. The Antarctic EPICA Dome C ice core dust record
(Lambert et al., 2008) has therefore been used to represent an inter-hemispheric response of dust generation to climate change on glacial/interglacial timescales (Köhler et al., 2010). The Antarctic record is genuinely different from the records shown in Fig. 3. Antarctica is a remote depositional site, whereas our records are located within globally significant ablation zones (Fig. 1).

Similarity between Red Sea and Chinese dust records suggests an atmospheric teleconnection across two major northern hemisphere dust producing regions. The abrupt climate variations documented in Greenland ice cores (Dansgaard et al., 1993) have been detected in the Chinese loess (Porter and An, 1995), Arabian Sea (Schulz et al., 1998) and Red Sea (Rohling et al., 2008). However, we here document for the first time that a detailed similarity exists between dust signals from China and Arabia, and that dust variability in these areas may be significantly different from that in circum-Saharan records (cf. Trauth et al., 2009). The observed dust peaks at deglaciations in the Arabia-China dust belt (Fig. 2d) appear to coincide with North Atlantic Heinrich events at the last 5 glacial terminations (Hodell et al., 2008). Heinrich events have been linked to intensified winter conditions with stronger westerly circulation over Eurasia, weakened summer monsoons and increased aridity in Eurasian deserts (Jin et al., 2007), and reduced summer monsoon-related upwelling in the Arabian Sea (Schulz et al., 1998). Large-scale atmospheric teleconnections therefore provide a credible explanation for the observed close relationship between variations in widely separated dust sources (Fig. 2d). By comparison, Saharan deflation is more related to changes in aridity associated with the position of the inter- 


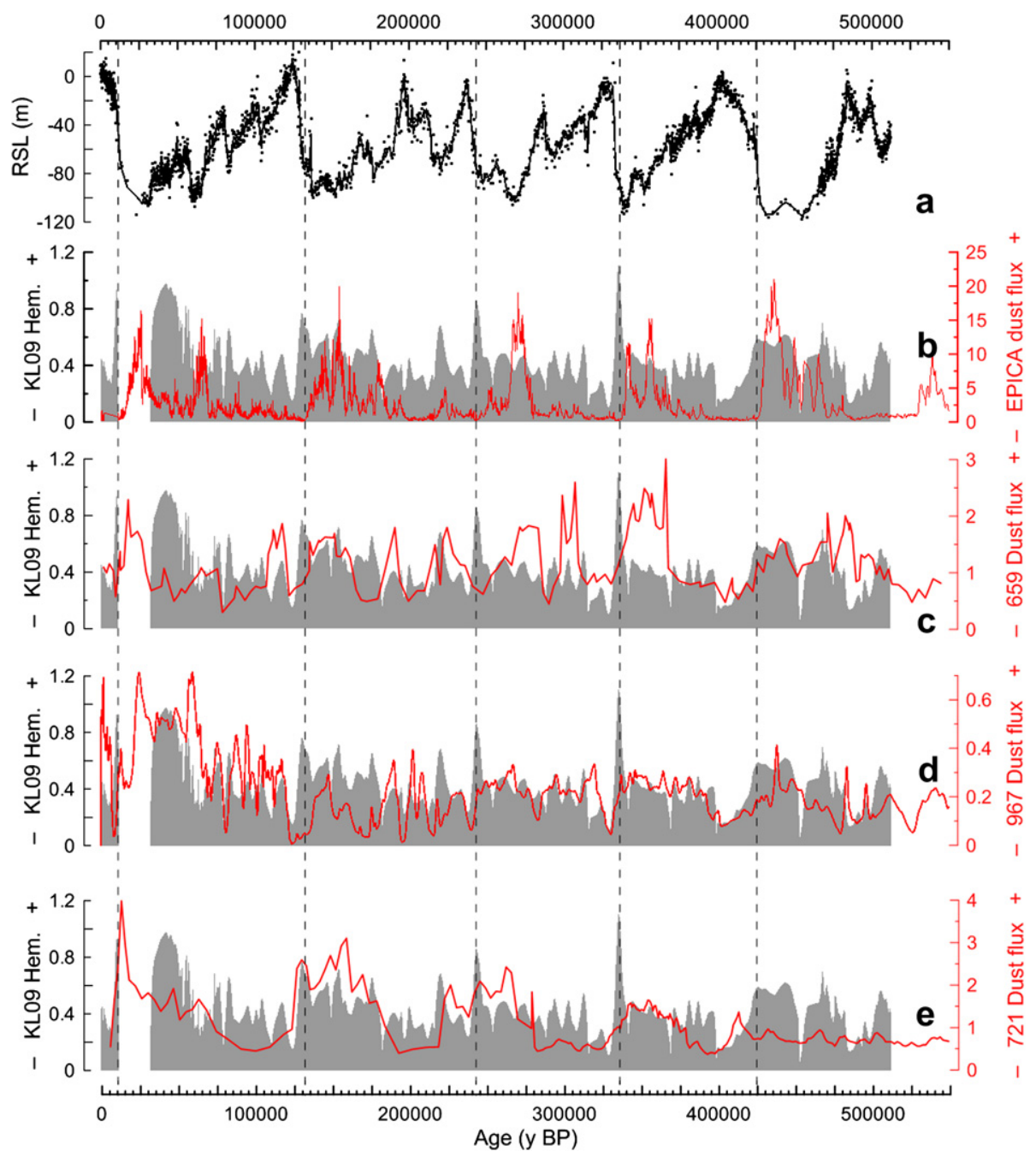

Fig. 3. Comparison of sea level and dust records from the Red Sea with those from Antarctica and around North Africa. (a) Sea level as in Fig. 2a. Comparison of dust records from core KL09 (grey shading) and (b) EPICA Dome C, Antarctica (Lambert et al., 2008); (c) ODP Site 659, off northwest Africa (Tiedemann et al., 1994); (d) ODP Site 967, Eastern Mediterranean Sea (Larrasoaña et al., 2003); and (e) ODP Site 721, Arabian Sea (deMenocal et al., 1991). Vertical dashed lines denote dust spikes at glacial terminations.

tropical convergence zone and to the intensity of tropical easterlies (e.g., Larrasoaña et al., 2003; Itambi et al., 2009). While millennialscale Saharan dust responses to Dansgaard-Oeschger and Heinrich events have been documented in high-resolution marine records (Moreno et al., 2002; Itambi et al., 2009), the largest Saharan dust fluxes occurred in glacials rather than during glacial terminations (e.g., Itambi et al., 2009), as is also shown in the records compiled in Fig. 3.

\section{Conclusions}

We conclude first that large regional differences in dust fluxes from major dust producing regions indicate that understanding global dust cycle variability on glacial/interglacial timescales requires separate treatment of the easterly-dominated low-latitude Sahara and the westerly-dominated dust belt from Arabia to China. Modelling studies can be improved by incorporating regional zones with different source variability. Second, dust flux patterns for the Arabia-China dust belt also contrast with the Antarctic ice core records (Lambert et al., 2008) that are increasingly used to assess climatic responses to changes in radiative forcing (e.g., Köhler et al., 2010). The distal response records from Antarctica have sharply delineated glacial/interglacial contrasts compared to the more proximal records shown in Figs. 2 and 3, which have a much higher total dust flux, a higher baseline of dust emissions through interglacials, and considerable high-frequency variability throughout the records. Studies that rely on Antarctic dust records to represent global atmospheric dust loadings will therefore erroneously overestimate the radiative contrast of aerosol loadings on glacial/interglacial timescales. Furthermore, the radiative forcing effect of atmospheric dust at low latitudes is up to an order of magnitude greater than at polar latitudes (Claquin et al., 2003). Third, further proximal dust flux records are needed from all major global dust source regions in order to properly constrain the spatial and temporal source variability and radiative impact of atmospheric dust loadings for use in climate models. Such records should resolve millennialscale responses of the dust cycle to abrupt climate changes. Fourth, correlation of our Red Sea record with Chinese loess records makes it possible to export our U-Th validated chronology, which enables millennial-scale correlation of the Chinese records with other global records for the first time.

\section{Acknowledgements}

This study contributes to UK Natural Environment Research Council projects NE/C003152/1, NE/H004424/1 and NE/E01531X/1. 


\section{References}

Arimoto, R., 2001. Eolian dust and climate: relationships to sources, tropospheric chemistry, transport and deposition. Earth-Science Reviews 54, 29-42.

Boyd, P.W., Ellwood, M.J., 2010. The biogeochemical cycle of iron in the ocean. Nature Geoscience 3, 675-682.

Cande, S.C., Kent, D.V., 1995. Revised calibration of the geomagnetic polarity time scale for the late Cretaceous and Cenozoic. Journal of Geophysical Research 100, 6093-6095.

Claquin, T., Roelandt, C., Kohfeld, K.E., Harrison, S.P., Tegen, I., Prentice, I.C., Balkanski, Y., Bergametti, G., Hansson, M., Mahowald, N., Rodhe, H., Schulz, M., 2003. Radiative forcing of climate by ice-age atmospheric dust. Climate Dynamics 20, 193-202.

Croudace, I.W., Rindby, A., Rothwell, R.G., 2006. ITRAX: description and evaluation of a new multi-function X-ray core scanner. In: Geological Society of London Special Publication, vol. 267, 51-63.

Dansgaard, W., Johnsen, S.J., Clausen, H.B., Dahl-Jensen, D., Gundestrup, N.S., Hammer, C.U., Hvidberg, C.S., Steffensen, J.P., Sveinbjörnsdottir, A.E., Jouzel, J., Bond, G., 1993. Evidence for general instability of past climate from a 250-kyr ice-core record. Nature 364, 218-220.

deMenocal, P., Bloemendal, J., King, J., 1991. A rock-magnetic record of monsoonal dust deposition to the Arabian Sea: evidence for a shift in the mode of deposition at 2.4 Ma. Proceedings of the Ocean Drilling Program, Scientific Results 177, 389-407.

Duce, R.A., Liss, P.S., Merrill, J.T., Atlas, E.L., Buat-Menard, P., Hicks, B.B., Miller, J.M., Prospero, J.M., Arimoto, R., Church, T.M., Ellis, W., Galloway, J.N., Hansen, L., Jickells, T.D., Knap, A.H., Reinhardt, K.H., Schneider, B., Soudine, A., Tokos, J.J., Tsunogai, S., Wollast, R., Zhou, M., 1991. The atmospheric input of trace species to the world ocean. Global Biogeochemical Cycles 5, 193-259.

Hodell, D.A., Channell, J.E.T., Curtis, J.H., Romero, O.E., Röhl, U., 2008. Onset of "Hudson Strait" Heinrich events in the eastern North Atlantic at the end of the middle Pleistocene transition ( $640 \mathrm{ka})$ ? Paleoceanography 23, PA4218. doi:10.1029/2008PA001591.

Intergovernmental Panel on Climate Change, 2007. Changes in atmospheric constituents and in radiative forcing. In: Climate Change 2007: The Physical Science Basis. Contribution of Working Group I to the Fourth Assessment Report of the Intergovernmental Panel on Climate Change. Cambridge University Press.

Itambi, A.C, von Dobeneck, T. Mulitza, S., Bickert, T. Heslop, D., 2009. Millennialscale northwest African droughts related to Heinrich events and Dansgaard-Oeschger cycles: evidence in marine sediments from offshore Senegal. Paleoceanography 24, PA1205. doi:10.1029/2007PA001570.

Jickells, T.D., An, Z.S., Anderson, K.K., Baker, A.R., Bergametti, G., Brooks, N., Cao, J.J., Boyd, P.W. Duce, R.A., Hunter, K.A., Kawahata, H., Kubilay, N., laRoche, J., Liss, P.S., Mahowald, N., Prospero, J.M., Ridgwell, A.J., Tegen, I., Torres, R., 2005. Global iron connections between desert dust, ocean biogeochemistry, and climate. Science 308, 67-71.

Jin, L., Chen, F., Ganopolski, A., Claussen, M., 2007. Response of East Asian climate to Dansgaard/Oeschger and Heinrich events in a coupled model of intermediate complexity. Journal of Geophysical Research 112, D06117. doi:10.1029/ 2006JD007316

Kaufman, Y.J., Tanré, D., Boucher, O., 2002. A satellite view of aerosols in the climate system. Nature 419, 215-223.

Köhler, P., Bintanja, R., Fischer, H., Joos, F., Knutti, R., Lohmann, G., MassonDelmotte, V., 2010. What caused earth's temperature variations during the last 800,000 years? Data-based evidence on radiative forcing and constraints on climate sensitivity. Quaternary Science Reviews 29, 129-145.

Lambert, F., Delmonte, B., Petit, J.R., Bigler, M., Kaufmann, P.R., Hutterli, M.A., Stocker, T.F., Ruth, U., Steffensen, J.P., Maggi, V., 2008. Dust-climate couplings over the past 800,000 years from the EPICA Dome C ice core. Nature 452, 616-619.

Larrasoaña, J.C., Roberts, A.P., Rohling, E.J., Winklhofer, M., Wehausen, R., 2003. Three million years of monsoon variability over the northern Sahara. Climate Dynamics 21, 689-698.

Liu, Q., Roberts, A.P., Rohling, E.J., Zhu, R., Sun, Y., 2008. Post-depositional remanent magnetization lock-in and the location of the Matuyama-Brunhes geomagnetic reversal boundary in marine and Chinese loess sequences. Earth and Planetary Science Letters $275,102-110$.

Maher, B.A., Prospero, J.M., Mackie, D., Gaiero, D., Hesse, P.P., Balkanski, Y., 2010. Global connections between aeolian dust, climate and ocean biogeochemistry at the present day and at the last glacial maximum. Earth-Science Reviews 99, 61-97.
Mahowald, N.M., Muhs, D.R., Levis, S., Rasch, P.J., Yoshioka, M., Zender, C.S., Luo, C., 2006. Changes in atmospheric mineral aerosols in response to climate: last glacial period, preindustrial, modern, and doubled carbon dioxide climates. Journal of Geophysical Research 111, D10202. doi:10.1029/2005JD006653.

Martin, J.H., Gordon, R.M., Fitzwater, S.E., 1991. The case for iron. Limnology and Oceanography 36, 1793-1802.

Martinez-Garcia, A., Rosell-Melé, A., Geibert, W., Gersonde, R., Masqué, P., Gaspari, V., Barbante, C., 2009. Links between iron supply, marine productivity, sea surface temperature, and $\mathrm{CO}_{2}$ over the last 1.1 Ma. Paleoceanography 24 , PA1207. doi:10.1029/2008PA001657.

Moreno, A., Cacho, I., Canals, M., Prins, M.A., Sánchez-Goñi, M.-F., Grimalt, J.O., Weltje, G.J., 2002. Saharan dust transport and high-latitude glacial climatic variability: the Alboran Sea record. Ouaternary Research 58, 318-328.

Mulitza, S., Heslop, D., Pittauerova, D., Fischer, H.W., Meyer, I., Stuut, J.-B., Zabel, M., Mollenhauer, G., Collins, J.A., Kuhnert, H., Schulz, M., 2010. Increase in African dust flux at the onset of commercial agriculture in the Sahel region. Nature 466, 226-228.

Porter, S.C., An, Z., 1995. Correlation between climate events in the North Atlantic and China during the last glaciation. Nature 375, 305-308.

Prospero, J.M., Ginoux, P., Torres, O., Nicholson, S.E., Gill, T.E., 2002. Environmental characterization of global sources of atmospheric soil dust identified with the NIMBUS 7 Total Ozone Mapping Spectrometer (TOMS) absorbing aerosol product. Reviews of Geophysics 40, 1002. doi:10.1029/2000RG000095.

Roberts, A.P., 2006. High-resolution magnetic analysis of sediment cores: strengths, limitations and strategies for maximizing the value of long-core magnetic data. Physics of the Earth and Planetary Interiors 156, 162-178.

Rohling, E.J., Grant, K., Hemleben, C., Kucera, M., Roberts, A.P., Schmeltzer, I., Schulz, H., Siccha, M., Siddall, M., Trommer, G., 2008. New constraints on the timing of sea level fluctuations during early to middle marine isotope stage 3. Paleoceanography 23, PA3219. doi:10.1029/2008PA001617.

Rohling, E.J., Grant, K., Bolshaw, M., Roberts, A.P., Siddall, M., Hemleben, C., Kucera, M., 2009. Antarctic temperature and global sea level closely coupled over the past five glacial cycles. Nature Geoscience 2, 500-504.

Rohling, E.J., Braun, K., Grant, K., Kucera, M., Roberts, A.P., Siddall, M., Trommer, G., 2010. Comparison between Holocene and marine isotope Stage-11 sea-level histories. Earth and Planetary Science Letters 291, 97-105.

Sassen, K., DeMott, P.J., Prospero, J.M., Poellot, M.R., 2003. Saharan dust storms and indirect aerosol effects on clouds: CRYSTAL-FACE results. Geophysical Research Letters 30, 1633. doi:10.1029/2003GL017371.

Schulz, H., von Rad, U., Erlenkeuser, H., 1998. Correlation between Arabian Sea and Greenland climate oscillations of the past 110,000 years. Nature 393, 54-57.

Spracklen, D.V., Carslaw, K.S., Kulmala, M., Kerminen, V.M., Sihto, S.L., Riipinen, I., Merikanto, J., Mann, G.W., Chipperfield, M.P., Wiedensohler, A., Birmili, W., Lihavainen, H., 2008. Contribution of particle formation to global cloud condensation nuclei concentrations. Geophysical Research Letters 35, L06808. doi:10.1029/2007GL033038.

Stein, M., Almogi-Labin, A., Goldstein, S.L., Hemleben, C., Starinsky, A., 2007. Late Quaternary changes in desert dust inputs to the Red Sea and Gulf of Aden from ${ }^{87} \mathrm{Sr} /{ }^{86} \mathrm{Sr}$ ratios in deep-sea cores. Earth and Planetary Science Letters 261, 104-119.

Sun, Y., Clemens, S.C., An, Z., Yu, Z., 2006. Astronomic timescale and palaeoclimatic implication of stacked 3.6-Myr monsoon records from the Chinese Loess Plateau. Quaternary Science Reviews 25, 33-48.

Tegen, I., Lacis, A.A., Fung, I., 1996. The influence on climate forcing of mineral aerosols from disturbed soils. Nature 380, 419-422.

Tiedemann, R., Sarnthein, M., Shackleton, N.J., 1994. Astronomical timescale for the Pliocene Atlantic $\delta^{18} \mathrm{O}$ and dust flux records of Ocean Drilling Program site 659. Paleoceanography 9, 619-638.

Trauth, M.H., Larrasoaña, J.C., Mudelsee, M., 2009. Trends, rhythms and events in Plio-Pleistocene African climate. Quaternary Science Reviews 28, 399-411.

Winckler, G., Anderson, R.F., Fleisher, M.Q., McGee, D., Mahowald, N., 2008. Covariant glacial-interglacial dust fluxes in the equatorial Pacific and Antarctica. Science 320, 93-96.

Wolff, E.W., Fischer, H., Fundel, F., Ruth, U., Twarloh, B., Littot, G.C., Mulvaney, R., Röthlisberger, R., de Angelis, M., Boutron, C.F., Hansson, M., Jonsell, U., Hutterli, M.A., Lambert, F., Kaufmann, P., Stauffer, B., Stocker, T.F., Steffensen, J.P., Bigler, M., Siggaard-Andersen, M.L., Udisti, R., Becagli, S., Castellano, E., Severi, M., Wagenbach, D., Barbante, C., Gabrielli, P., Gaspari, V., 2006. Southern ocean sea-ice extent, productivity and iron flux over the past eight glacial cycles. Nature 440, 491-496. 